\title{
PEMBAHARUAN HUKUM ISLAM DI INDONESIA Refleksi Pemikiran Ahmad Azhar Basyir Tentang Aktualisasi Hukum Islam
}

\author{
Muslim MS
}

\begin{abstract}
Ahmad Azhar Basyir initiated some ideas, especially in area of fiqih. For him, fiqih is not only simply expression of classic idea, but rather as appearance a set modern idea. Hence, no wonder in this field, Azhar Basyir yielded a typical methodology. This methodology can obviously colour almost entire his works, including in philosophy, law, theology, and misticism (tasawuf).
\end{abstract}

Keywords: Islamic law, modernization, and actualization.

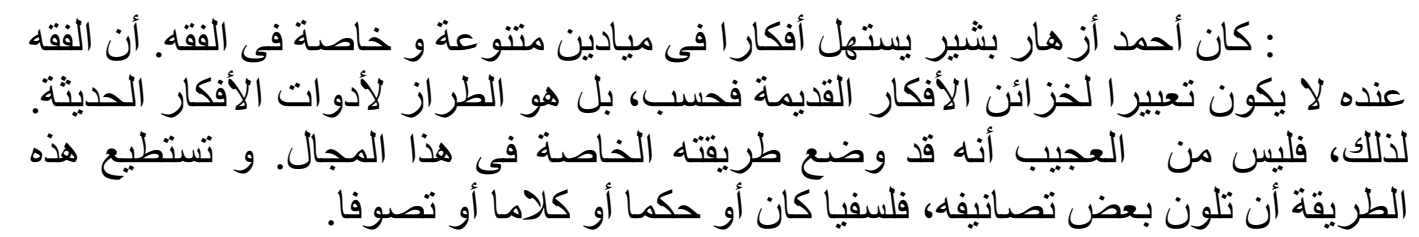

\section{Pendahuluan}

Di tengah maraknya arus pembaruan hukum Islam di Indonesia, Ahmad Azhar Basyir tampil menjadi salah seorang pemikir yang mempunyai karakteristik tersendiri dalam memperkaya khazanah pemikiran hukum Islam yang ada. Pembaruan pemikirannya dalam bidang hukum Islam dapat ditelusuri melalui dua pendekatan. Pertama, pendekatan qauli (menekankan sisi hasil pemikiran semata [fiqih]), dan kedua, pendekatan manhaji (menekankan segi metodologi [ushul fiqh]). ${ }^{1}$

Azhar Basyir sebagai pakar hukum sekaligus peminat filsafat menunjukkan problematik tentang cara rekonstruksi pemikiran yang sampai saat ini dianggap menjadi lebih mapan. Rekonstruksi ini dilakukan dengan metodologi yang lebih jelas terhadap karya-karya para pemikir muslim lainnya dan sekaligus menjadikannya perangkat pemikiran yang inspiratif (memiliki dasar yang kukuh dari al-Qur`an dan Hadis) dan juga relevan dengan syari'at Islam.

\section{Kontemplasi Kontekstual Hukum Islam}

Ajaran Islam yang mengatur tatacara hidup disebut hukum, dalam ilmu ushul figh, hukum didefinisikan sebagai "titah Allah yang berhubungan dengan perbuatan orang-orang mukallaf, berupa tuntutan untuk melakukan sesuatu yang berarti perintah yang wajib dikerjakan, atau tuntutan meninggalkan sesuatu yang berarti larangan dan haram dikerjakan, atau ketetapan hukum itu berupa hal yang mubah (fakultatif), yang berarti boleh dikerjakan dan boleh ditinggalkan, maupun ketetapan hukum yang menjadikan dua hal berkaiatan dan salah satu menjadi sebab atau syarat atau rintangan terhadap yang lain. ${ }^{2}$ 
Mushthafa Ahmad al-Zarqa` menyebutkan cakupan hukum Islam meliputi hukum akidah, ibadah, keluarga, muamalah, jinayah, tatanegara, hukum antar negara dan adab sopan santun. Untuk membatasi masalah yang dibahas maka tulisan ini tidak menyinggung masalah akidah, ibadah, dan adab sopan santun. ${ }^{3}$

Hukum Islam ada yang diperoleh melalui ketentun nash al-Qur`an atau Sunnah dan ada pula yang diperoleh melalui ijtihad. Nash al-Qur`an dan Sunnah dalam menunjuk ketentuan hukum ada yang bersifat rinci (tafshili) dan garis besar (mujmal), ada yang pasti (qath'i) dan ada yang tidak pasti (zhanni). ${ }^{4}$ Terhadap nash hukum yang qath'iy tidak terdapat perbedaan pemahaman di kalangan fuqaha', sedangkan terhadap nash hukum yang zhanni terdapat perbedaan pemahaman di kalangan fuqaha'. Nash hukum yang menunjuk ketentuan hukum secara rinci bernilai qath'i, sedangkan nash hukum yang menunjuk ketentuan hukum secara garis besar berupa kaidah-kaidah pokok, memungkinkan penggunaan akal untuk melakukan rincian. Menurut Ahmad Azhar Basyir, menggunakan akal untuk melakukan rincian terhadap nash-nash hukum yang menunjuk ketentuan hukum secara garis besar menjadi ruang gerak ijtihad. ${ }^{5}$ Ruang gerak ijtihad akan semakin luas dalam menentukan hukumhukum yang tidak disebutkan dalam nash. Hukum-hukum yang tidak disebutkan dalam nash dan harus ditetapkan dengan jalan ijtihad harus memperhatikan jiwa dan tujuan ketentuan nash khususnya, dan jiwa serta tujuan ajaran Islam pada umumnya yang sering disebut ruh dan maqashid al-syari'ah. ${ }^{6}$

Dalam pandangan Azhar Basyir, ruh syari'ah menempatkan manusia sebagai makhluk ciptaan Allah yang dalam menjalani hidup di dunia melaksankaan pengabdian kepada Allah, dan maqashid atau tujuan syari'ah adalah mendidik pribadi agar menjadi manusia yang bermanfaat bagi masyarakatnya, menegakkan keadilan dan mewujudkan kebaikan dalam kehidupan. $^{7}$

Mengenai kaitan hukum Islam dengan realitas sosial, Azhar Basyir menyatakan bahwa suatu hal yang mustahil diingkari adalah adanya kaitan hukum nash dengan realitas sosial pada saat nash diturunkan atau dinyatakan, baik berupa ayat-ayat al-Qur`an maupun Sunnah Rasulullah saw. ${ }^{8}$ Beberapa nash hukum mencerminkan realitas sosial di tempat dan pada saat dinashkan. Misalnya, ayat hukum zhihar berkaitan dengan kebiasaan yang berlaku di kalangan bangsa Arab, yaitu suami mengatakan keadaan isteri ibarat punggung ibunya, sehingga berakibat isteri haram digauli.

Dalam zhihar, Fyzee menulis, suami bersumpah baginya isterinya seperti punggung ibunya. Setelah sumpah yang dilakukan itu, isteri memiliki hak mengajukan perceraian atau pengganti-rugian atas hak-hak yang berhubungan dengan perkawinan sebagai hukuman ke pengadilan. Praktek semacam ini merupakan bentuk dan persoalan-persoalan kuno dari masyarakat pra-Islam. ${ }^{9}$

Dengan zhihar, hubungan suami isteri belum putus, tetapi isteri tidak boleh digauli. Kedudukan isteri menjadi terkatung-katung, nafkah tidak diberi, untuk 
kawin dengan orang lain tidak mungkin, sebab perkawinan mereka belum putus. Tindakan sewenang-wenang sang suami terhadap isterinya demikian itu dicela oleh syari'at Islam. Suami yang menzhihar isterinya dinyatakan berdosa, karena telah mengakibatkan haramnya isteri digauli sebagaimana haramnya seorang laki-laki menggauli ibunya. Dengan jalan qiyas, isteri yang di-zhihar suaminya diberi kesempatan menunggu waktu selama empat puluh hari, seperti pada sumpah ila', sumpah suami tidak akan menggauli isterinya. Jika setelah empat puluh hari suami mengambil keputusan cerai, maka jatuhlah talak ba in kubra. Demikian halnya jika keputusan ditetapkan melanjutkan perkawinan, maka suami harus membayar kifarat berupa memerdekakan budak sebelum mengauli isterinya. Jika memerdekakan budak tidak mungkin, maka diganti dengan puasa dua bulan berturut-turut, jika tidak kuat diganti dengan memberi makan enam puluh orang miskin.

Sesuai dengan konteksnya, ayat tentang zhihar itu dimaksud untuk memperbaiki kebiasaan orang Arab jahiliyah yang merupakan penganiayaan terhadap isteri. Apakah ayat tentang zhihar berlaku juga untuk konteks Indonesia yang tidak mengenal kebiasaan zhihar? Menurut Azhar Basyir, kebiasaan zhihar tidak dikenal di Indonesia, dengan demikian zhihar tidak perlu dimasukkan dalam salah satu ketentuan hukum perkawinan di Indonesia. ${ }^{10}$

Dari contoh itu diketahui jika ketentuan hukum berkaitan dengan realitas sosial yang tidak merata dilakukan manusia di tempat-tempat lain, maka ketentuan hukum tersebut juga tidak bersifat umum, meskipun tercantum dalam nash al-Qur'an atau Sunnah.

Tetapi jika ketentuan nash merupakan hal yang dilakukan manusia di semua tempat, maka ketentuannya berlaku umum. ${ }^{11}$ Misalnya 'iddah (masa tunggu) bagi janda yang dicerai atau ditinggal mati oleh suaminya, larangan kawin bagi wanita yang dalam ikatan perkawinan, kewajiban memberi nafkah suami bagi isterinya, ancaman pidana terhadap delik zina, larangan makan riba bagi umat beriman, dan sebagainya. Nash-nash hukum yang diberlakukan terhadap umat beriman di mana pun dan kapan pun itu, tidak perlu dikaitkan dengan konteks sosio-kultural masyarakat di tempat dan di saat turunnya nashnash hukum bersangkutan, karena maslahat yang terkandung dalam nash-nash hukum itu sifatnya universal dan sesuai dengan tuntutan fitrah manusia.

Ada beberapa ketentuan dalam nash-nash yang dipertayakan 'illat hukumnya berkaitan dengan realitas sosial di tempat dan saat nash-nash diturunkan dan 'illat hukum itu kemudian dijadikan dasar dalam menentukan, apakah kandungan nash-nash hukum itu berlaku lokal dan temporal, atau berlaku universal. Misalnya ayat hukum tentang batas-batas aurat wanita yang dijelaskan juga oleh Sunnah, bahwa yang bukan aurat pada wanita hanya telapak tangan dan muka. Ada yang mengemukakan 'illat ketentuan hukum tersebut adalah kejiwaan seksual bangsa Arab yang tidak tahan melihat wanita terbuka bagian tubuhnya kecuali muka dan telapak tangan. Sebagai konsekuensi 
logisnya, pandangan semacam ini menganggap bahwa nash-nash hukum tentang hal ini berlaku lokal dan temporal. Ada pula yang mengemukakan bahwa secara fitri, laki-laki di mana pun akan mudah terangsang oleh aurat wanita (selain muka dan telapak tangan), maka konsekuensi logisnya nash-nash hukum tentang hal ini berlaku universal dan permanen. Menurut Azhar Basyir, orang akan lebih hati-hati apabila berpegang pada pendapat dan pandangan yang kedua ini, karena lebih selamat dalam menghadapi trend perkembangan kebudayaan yang semakin mengarah kepada longgarnya norma-norma hukum sebagaimana telah menjadi fenomena dewasa ini. ${ }^{12}$

Selanjutnya Azhar Basyir menyatakan, bahwa berijtihad yang tidak disebutkan dalam nash al-Qur`an dan Sunnah, dapat ditempuh dengan berbagai cara. ${ }^{13}$ Jika hukum yang dicari terdapat persamaan dengan yang disebut dalam nash, maka dapat digunakan analogi (qiyas). Qiyas adalah menyamakan hukum sesuatu yang tidak disebutkan dalam nash dengan hukum secara tegas disebutkan dalam nash karena adanya persamaan 'illat atau kausanya. Misalnya, zakat perikanan darat diqiyaskan dengan zakat tanaman, sehingga nishabnya seharga nishab hasil tanaman, yaitu 7,5 kwintal beras, dan zakatnya pun seperti kadar zakat tanaman, yaitu 5\%. Menurut Azhar Basyir, ijtihad ini disebut dengan ijtihad qiyasi. ${ }^{14}$

Jika ketentuan hukum yang dicari adalah hal yang sama sekali tidak disebutkan dalam nash dan tidak ada persamaannya, maka harus dicari hubungannya dengan kehidupan masyarakat. Hal-hal yang tidak disebutkan dalam nash dan tidak memiliki persamaan dengan nash, tetapi merupakan hal yang sangat diperlukan (dihajatkan) bagi kehidupan masyarakat, maka digunakan metode ijtihad yang disebut istishlah, ijtihad seperti ini disebut ijtihad istishlahi. ${ }^{15}$ Misalnya Undang-undang mewajibkan pencatatan peristiwa nikah, guna memperoleh jaminan hukum mengenai hak-hak suami-isteri dalam perkawinan. Mewajibkan pendaftaran hal milik atas tanah bersertifikat, guna memperoleh kepastian dan jaminan hukum pemilikan.

Kepentingan-kepentingan hidup manusia (mashalih, bentuk jama' dari mashlahah), yang menjadi pertimbangan ditetapkannya hukum di luar nash, dibagi tiga: kepentingan-kepentingan esensial dalam kehidupan manusia seperti memelihara keselamatan agama, jiwa, akal dan harta (al-mashalih al-dharuriyah); kepentingan-kepentingan tak esensial tapi diperlukan dalam kehidupan manusia agar tidak mengalami kesempitan dan kesukaran yang jika tidak terpenuhi tidak akan mengakibatkan kerusakan dalam kehidupan manusia (al-mashalih al-hajiyat) dan kepentingan-kepentingan pelengkap yang jika tidak terpenuhi, tidak akan mengakibatkan kesempitan atau kesukaran dalam kehidupan manusia (almashalih al-tahsiniyat. ${ }^{16}$

Jika sesuatu hal ditentukan hukumnya di dalam nash, tetapi karena sesuatu kasus, yaitu bila ketentuan hukum tersebut dipertahankan akan berakibat bertentangan dengan ketentuan lain yang lebih umum, maka ketentuan khusus 
itu dapat ditingalkan guna memenuhi ketentuan yang lebih umum. Ijtihad semacam ini disebut ijtihad istihsani. ${ }^{17}$ Istihsan adalah memandang lebih baik meninggalkan dalil khusus untuk menerapkan dalil yang lebih umum. Misalnya, menurut dalil khusus pemerintah wajib menjamin keselamatan hak milik perorangan atas tanah. Tetapi jika tanah milik perorangan diperlukan untuk pembuatan waduk guna memenuhi kebutuhan dalam meningkatkan produksi pertanian yang menjadi kepentingan masyarakat luas, maka pemerintah berhak membebaskan tanah milik perorangan itu untuk direalisasikan menjadi waduk. Namun demikian, dalam pembebasan tanah milik perorangan untuk membangun waduk yang merupakan tuntutan kepentingan masyarakat luas itu nilai keadilan harus diperhatikan. Kepada pemilik tanah harus (wajib) diberikan ganti rugi yang layak dan seimbang dengan kepentingan pembuatan waduk dan diseimbangkan pula dengan perolehan kontraktor yang akan melaksanakan pembuatan waduk itu. Jangan sampai para pemilik tanah mendapat ganti rugi yang tidak layak, lebih-lebih jika mereka masih harus mengalami pemotongan secara tidak bertanggung jawab. Nilai keadilan dalam memberikan ganti rugi kepada pemilik tanah benar-benar tidak mengakibatkan kecemburuan sosial di kalangan para pemilik tanah yang dibebaskan, karena melihat profit (keuntungan) besar yang diperoleh pelaksana pembuatan waduk.

Jika suatu hal yang tidak disebutkan sama sekali di dalam nash, tidak pula merupakan tuntutan kepentingan masyarakat luas, maka untuk menentuan hukumnya dapat dilakukan dengan metode ijtihad istishhab dan ijtihad dengan metode ini dapat disebut ijtihad istishbahi.18 Istishhab adalah memberlakukan ketentuan hukum yang ada karena tidak terlihat adanya dalil yang mengalihkan kepada ketentuan hukum lain.

Isitishhab tidak menetapkan sesuatu hukum baru bagi sesuatu hal, tetapi hanya melangsungkan berlakunya hukum akal tentang kebolehan (ibahah) atau bebas asal (al-bara'ah al-ashliyah) atau melangsungkan berlakunya hukum syara' tentang sesuatu atas dasar terpenuhinya sebab terjadinya hukum. Karena itu, istishhab hanya menjadi hujjah untuk melangsungkan hukum yang telah ada, tidak menetapkan hukum baru. ${ }^{19}$

Kaidah fiqih menyebutkan, bahwa pada dasarnya segala bentuk muamalat hukumnya mubah berdasarkan kaidah al-ashlu fi al-mu'amalah al-ibahah. Hadis Nabi mengajarkan bahwa halal adalah yang dihalalkan Allah dalam kitab-Nya dan yang haram adalah yang diharamkan Allah dalam Kitab-Nya yang didiamkan oleh Allah adalah dimaafkan. Atas dasar hadis Nabi tersebut (selaras dengan kaidah fiqih di atas), maka segala macam muamalat yang belum pernah dikenal pada masa Nabi dan tidak mengandung unsur-unsur yang bertentangan dengan ketentuan hukum Islam, hukumnya mubah (boleh). Hukum mubah ini berlaku pada setiap bentuk muamalat yang tidak disebutkan di dalam nash dan akan terus berlangsung selama tidak terdapat dalil yang mengubah ketentuan 
asalnya. Ada atau tidaknya dalil yang menrubah dapat diketahui dari analisis unsur-unsur yang terdapat dalam muamalat yang bersangkutan.

Hal-hal yang hukumnya mubah, atas dasar sadd al-dzara'i (menutup pintu terjatuh dalam larangan) dapat diharamkan. Ijtihad macam ini kiranya dapat disebut ijtihad sadd al-dzara'i.20 Misalnya saja, surat al-Ma`idah ayat 5 yang membolehkan laki-laki muslim menikahi perempuan ahli kitab (Nasrani atau Yahudi). Tetapi jika perkawinan yang dibolehkan syara' itu pada suatu ketika berakibat melemahnya keagamaan laki-laki muslim yang mengawini perempuan ahli kitab, maka dengan jalan ijtihad sadd al-dzara'i, perkawinan tersebut dapat dilarang dan dihukumi haram.

Hal-hal yang menjadi ketentuan dalam hukum adat dapat dikukuhkan berlakunya menurut pandangan hukum Islam, sepanjang tidak bertentangan dengan ketentuan-ketentuan hukum Islam. Tradisi yang merupakan salah satu tonggak kehidupan masyarakat itu tidak selalu harus dihapuskan setelah masyarakat menerima ajaran Islam. Melestarikan berlakunya adat kebiasaan yang tidak bertentangan dengan hukum Islam itu pada hakikatnya merupakan tuntutan kebaikan atau kemaslahatan hidup bermasyarakat. Oleh karena itu, ijtihad yang mendasarkan kepada adat istiadat kemudian dikukuhkan sehingga menjadi bagian dari hukum Islam itu dapat dikategorikan ke dalam ijtihad istishlahi. ${ }^{21}$ Kaidah fiqih menyebutkan bahwa adat kebiasaan dikukuhkan sebagai hukum yang sah (al-'adah al-muhakkamah). Misalnya, ketentuan pasal 35 UU No. 1/1974 tentang perkawinan yang menentukan bahwa harta yang diperoleh selama perkawinan menjadi harta bersama dapat dikukuhkan dalam hukum Islam, karena latar belakang ketetuan tersebut adalah hukum adat Indonesia (Jawa) yang tidak bertentangan dengan ketentuan hukum Islam.

Dari uraian-uraian di atas, dapat ditegaskan bahwa dalam melakukan ijtihad, Azhar Basyir menggunakan metode-metode, yaitu qiyasi, istishlahi, istihsani, istishhabi, sadd al-dzara'i, dan 'urf. Nampaknya, metode ijtihad yang diterapkan ini tidak hanya terpaku pada salah satu metode dari imam-imam mujtahid terdahulu, akan tetapi merupakan akumulasi dari seluruh metode yang pernah diterapkan imam-imam mazhab terkemuka.

Hukum-hukum yang ditetapkan atas dasar ijtihad dapat mengalami perubahan-perubahan sesuai dengan berubahnya situasi, waktu dan tempat. Tidak demikian halnya hukum-hukum nash. Terhadap hukum-hukum nash tidak mungkin diadakan perubahan-perubahan. Kemungkinan yang terjadi pada hukum-hukum nash adalah ditetapkannya atau tidak, sejalan dengan 'illat hukum yang melatarbelakanginya, atau karena terjadi konflik maslahat antara nash khusus dan nash umum, atau karena tidak terpenuhinya persyaratanpersyaratan yang diperlukan untuk menerapkan ketentuan hukum nash. Misalnya, Umar bin Khattab tidak menerapkan hukuman pidana potong tangan terhadap pelaku pencurian di musim paceklik, karena tidak memenuhi kriteria atau syarat-syarat perbuatan pidana pencurian, dan seterusnya. ${ }^{22}$ 
Hukum-hukum nash berasal dari Allah, baik yang langsung berupa alQur`an ataupun yang tidak langsung berupa Sunnah. Hukum-hukum nash yang berasal dari Allah itu ditujukan kepada umat manusia ciptaan Allah SWT. Sudah tentu hukum-hukum Allah sejalan dengan fitrah manusia. Hukum yang sesuai dengan fitrah manusia yang paling baik bagi manusia. Menurut Azhar Basyir, pemikiran hukum Islam dalam konteks fitrah ini juga yang akan sejalan dengan ruh dan tujuan syariat Islam. ${ }^{23}$

Menurut Azhar Basyir, untuk berijtihad dapat dilakukan secara perorangan dan jama'i (kolektif). Menghadapi persoalan-persoalan hidup yang makin kompleks sekarang ini, mencari jalan pemecahan dengan jalan ijtihad jama'i akan lebih memantapkan hasil yang dicapai. Yang sangat urgen memperoleh perhatian ialah bagaimana usaha yang harus dilakukan untuk melahirkan tenaga mujtahidin yang berkualitas. ${ }^{24}$

\section{Aspek Moral dalam Hukum Islam}

Akhlak atau moralitas adalah perilaku jiwa dengan mudah dapat melahirkan perbuatan-perbuatan tanpa memerlukan pemikiran dan pertimbangan. Apabila perilaku tersebut mengeluarkan perbuatan baik dan terpuji menurut akal maupun tuntunan agama, disebut akhlak yang baik. Apabila perbuatan yang dikeluarkan itu buruk, disebut akhlak yang buruk. ${ }^{25}$

Nilai baik dan buruk dapat menyangkut sikap manusia terhadap Allah, Rasulullah saw., diri pribadi, keluarga, masyarakat dan alam sekitarnya. Jika berbicara tentang sikap manusia terhadap Allah dan Rasul-Nya, otomatis menyangkut tatanan hidup yang digariskan Allah dan Rasul-Nya kepada menusia, maka nilai baik buruk itu akan tercermin dalam perilaku manusia itu sendiri. Apakah manusia menerimanya dengan ikhlas atau menolaknya atau apakah tatanan itu mampu membimbing manusia menuju moralitas mulia, mem-pertahankan moralitas tinggi, mencegah dekadensi moral dalam masyarakat. Pendeknya, manusia sebagai makhluk Allah harus mau dan mampu mengaplikasikan nilai-nilai yang telah digariskan oleh Allah dan Rasul-Nya, kapan dan di mana pun berada. Hal ini sebagai perwujudan diutusnya Nabi Muhammad semata-mata menyem-purnakan akhlak dalam arti yang luas.

Bagi Muhammad saw. menyampaikan risalah dalam dua periode, periode Makkah dan Madinah. Periode Makkah selama dua belas tahun lebih menekankan pembinaan pribadi, menanamkan akidah tauhid dan membina akhlak luhur. Tauhid mengajarkan bahwa hanya Allah sajalah Tuhan yang menciptakan, mengatur dan memelihara semesta alam (tauhid rububiyah) dan bahwa hanya Allah sajalah Tuhan yang berhak disembah (tauhid uluhiyah). ${ }^{26}$ Tauhid uluhiyah menuntut agar manusia tunduk mutlak hanya kepada Allah. Tauhid rububiyah menuntut agar manusia menyadari jati dirinya sebagai makhluk ciptaan di bumi dan diberi kedudukan sebagai khalifah. Khalifah berarti wakil. Manusia menjadi wakil Allah untuk terlaksananya kehendak Allah, yaitu terwujudnya kemakmuran, kedamaian dan kesejahteraan di bumi. ${ }^{27}$ 
Sebagai wakil, dalam melakukan kewajibannya manusia tidak dibenarkan menyimpang dari garis-garis yang telah ditentukan oleh yang mewakilkannya. Dalam menjalani hidup di dunia ini, manusia wajib menghormati dan mentaati pedoman-pedoman yang diberikan Allah dan rasul-Nya. Menghormati dan mentaati pedoman-pedoman itu merupakan perwujudan moralitas luhur manusia kepada Allah dan Rasul-Nya.

Pedoman hidup bermasyarakat dan ibadah secara terinci diberikan ketika Nabi sudah hijrah ke Madinah. Umat Islam tidak menghadapi kesulitan dan keberatan apa pun dalam menerima pedoman hidup bermasyarakat dan ibadah yang terinci di Madinah, karena akidah dan akhlaknya sudah tertanam dengan kuat ketika berada di Makkah. Pedoman-pedoman bermasyarakat pada umumnya diberikan berupa kaidah-kaidah umum, guna menampung perkembangan yang dialami umat manusia dalam perjalanan sejarah hidupnya. Wahyu yang berupa al-Qur`an dan Sunnah merupakan sumber utama ajaran Islam, sedang hal-hal yang belum diaturdengan jelas diupayakan untuk mencarinya dengan ijtihad. Dalam sejarah perkembangan hukum Islam ijtihad telah memainkan peran dan memberi porsi yang cukup besar, hingga timbulnya mazhab-mazhab.

Jika mengkaji hukum Islam secara seksama maka akan ditemui banyak aturan yang sarat dengan moralitas. Di dalamnya dijumpai ketentuan hukum yang benar-benar membina moralitas luhur, baik moralitas individual maupun moralitas kolektif. Dalam hukum pidana Islam misalnya, terdapat ketentuan bahwa orang yang melakukan hubungan seksual diluar nikah diancam dengan pidana cambuk seratus kali di depan umum (QS. 24: 2). Zina menurut ajaran Islam dinilai sebagai perbuatan keji dan merupakan jalan terburuk yang ditempuh manusia beradab (QS. 17: 32). Makan riba dilarang karena merupakan kezaliman terhadap kaum lemah (QS. 2: 278-279). Kreditur supaya memberi kelonggaran waktu (tanpa memungut bunga) kepada debitur yang mengalami kesulitan untuk membayar kembali utangnya pada waktu yang telah dijanjikan. Jika debitur sungguh-sungguh tidak mampu lagi melunasi utangnya, kreditur supaya menyedekahkannya (QS. 2: 280). Hukum Islam melarang pedagang mengurangi hak pembeli, baik dalam takaran, timbangan maupun ukuran (QS. 11: 85). Nabi mengajarkan bahwa memperlambat membayar utang setelah jatuh tempo bagi debitur yang telah mampu merupakan kezaliman (HR. BukhariMuslim). ${ }^{28}$

Menurut Azhar Basyir, beberapa pesan al-Qur`an tentang hukum Allah dan Rasul-Nya dapat disajikan sebagai berikut:

1. Agar orang tidak mengutamakan hukum jahiliyah daripada hukum Allah karena hukum Allah adalah yang terbaik (sesuai fitrah manusia) di antara hukum yang ada (QS. 5: 50).

2. Memutuskan perkara hendaknya mengikuti ketentuan wahyu Allah, tidak mengikuti hawa nafsu kebanyakan orang (QS. 5: 48).

3. Orang akan menyatakan mendengar dan taat, manakala diajak kembali berhukum kepada Allah dan Rasul-Nya (QS. 24: 51).

4. Orang mukmin akan menyelesaikan perkara di antara mereka dengan hukum Allah dan Rasul-Nya, terhadap ketentuan hukum Allah dan 
Rasul-Nya mereka bersikap menerima dengan rela dan penuh penyerahan (QS. 4: 65).

5. Orang mukmin laki-laki maupun perempuan tidak patut menentukan pilihan lain, jika ketentuan Allah dan Rasul-Nya telah ditetapkan (QS. 33: 36).

6. Menetapkan hukum atas dasar keinginan kebanyakan orang akan memalingkan perhatian dari hukumAllah (QS. 5: 49).

7. Hukum Allah, hukum Rasul dan ketetapan ulul amri (yang tidak berlawanan dengan hukum Allah dan Rasul-Nya) wajib ditaati (QS 4: 59). ${ }^{29}$

Dengan norma-norma moralitas khusus hukum Allah meletakkan aturanaturan universal bagi perbuatan manusia. ${ }^{30}$ Karena ada ukuran yang pasti pada moral Islam, maka pergeseran dalam moral masyarakat Islam mempunyai lapangan yang sangat sempit. Artinya, pertumbuhan yang menyimpang dari alur-alur yang semula dikira baik atau buruk kemudian melenceng sedemikian rupa sedikit sekali kemungkinannya. ${ }^{31}$

Dalam masyarakat Islam, hukum merupakan faktor utama yang memberikannya bentuk. Masyarakat Islam idealnya harus sesuai dengan kitab hukum, sehingga tidak ada perubahan sosial yang mengacaukan atau menimbulkan karakter tak bermoral dalam masyarakat. Hukum Islam harus berjalan sesuai dengan prinsip-prinsip moralitas seperti yang dinyatakan oleh Islam. Hukum Islam memberikan ketentuan bahwa kaidah kesusilaan tidak boleh bertentangan dengan syarat-syarat yang termaktub dalam al-Qur`an dan Sunnah. ${ }^{32}$ Dengan ini nyatalah bahwa hukum Islam menuju kepada kesusilaan yang lebih pasti isinya dan lebih tetap mutu dan haluannya, karena Islam tidak membiarkan semuanya hanya tergantung pada masyarakat dan manusia saja. ${ }^{33}$

Syari'at Islam adalah kode hukum dan kode moral sekaligus. Ia merupakan pola yang luas tentang tingkah laku manusia yang berasal dari otoritas kehendak Allah yang tertinggi, sehingga garis pemisah antara hukum dan moralitas sama sekali tidak bisa ditarik secara jelas seperti pada masyarakat Barat pada umumnya. Itulah sebabnya mengapa misalnya, kepentingan dan signifikansi semacam itu melekat pada keputusan ulama. ${ }^{34}$

H.A.R. Gibb menulis, hukum Islam memiliki jangkauan paling jauh dan alat efektif dalam membentuk tatanan sosial dan kehidupan masyarakat Islam. Otoritas moral hukum Islam membentuk struktur sosial Islam yang rapi dan aman melalui semua fluktuasi keberuntungan politis. Hukum Islam memiliki norma-norma etika baik dan buruk, kejahatan dan kebajikan yang masyarakat secara ideal harus menyesuaikan diri dengannya. Oleh karena itu, hukum Islam mempengaruhi semua aspek kehidupan sosial, ekonomi, dan semua aspek lainnya. 35

\section{Aktualisasi Hukum Islam di Indonesia}

Gairah untuk mengkaji Hukum Islam di Indonesia pada dekade terakhir ini sangat menggembirakan karena banyak faktor. Rasa keberagaman di kalangan 
kaum muslim menunjukkan kecenderungan meningkat, sehingga kesadaran akan aktivitas dan kewajiban melaksanakan ajaran Islam yang diyakini sebagai curahan rahmat kasih sayang Allah kepada semesta alam pun meningkat pula. ${ }^{36}$

Dalam pandangan Azhar Basyir, hukum Islam merupakan bagian integral ajaran Islam yang tidak mungkin bisa dilepas atau dipisahkan dari kehidupan umat Islam, atas dasar keyakinan keislamannya. Oleh karenanya, kaum muslim akan mengalami ketenteraman batin dalam kehidupan beragama, jika hukum Islam menjadi landasan dan tatanan hidup mereka, yang memperoleh dukungan penuh dari negara, dengan dikukuhkan dalam peraturan perundang-undangan. Hal ini di negara Republik Indonesia, dengan Pancasila sebagai falsafah dasar negara dan UUD 1945 sebagai dasar konstitusionalnya, bukan saja hanya dimungkinkan bahkan merupakan keharusan konstitusional yuridis. ${ }^{37}$

Beberapa bagian hukum Islam benar-benar telah diangkat dalam peraturan perundang-undangan, baik secara tersurat maupun sersirat. UU No. 5/1960 tentang Peraturan Dasar Pokok-Pokok Agraria melindungi perwakafan tanah milik telah dikeluarkan Peraturan Pemerintah (PP) No. 28/1977. UU No. 4/1979. tentang kesejahteraan anak juga mencantumkan ketentuan hukum Islam, yaitu pada penjelasan pasal 12 bahwa pengangkatan anak tidak memutuskan hubungan darah anak angkat dengan orang tuanya berdasarkan hukum anak angkat bersangkutan. UU No. 1/1974 tentang Perkawinan menentukan bahwa sahnya perkawinan harus dilakukan menurut hukum agama dan kepercayaannya masing-masing. Dalam beberapa pasalnya terdapat klausulklausul pelarian, bahwa ketentuan-ketentuan yang tercantum dalam pasal tertentu dikecualikan jika hukum agama atau kepercayaannya itu masingmasing menentukan lain.

Dalam hubungannya dengan pembangunan Hukum Nasional, menurut Azhar Basyir, kaum muslimin selalu memperoleh kesempatan untuk menyajikan konsep-konsep hukum Islam, agar peraturan-peraturan perundang-undangan yang berlaku juga bagi kaum muslimin tidak menyimpang dari ketentuan hukum Islam. Lebih-lebih yang khusus berlaku bagi kaum muslimin yang menjadi wewenang Peradilan Agama. Telah dibuat rancangan undang-undang tentang Hukum Acara Peradilan Agama. Untuk pegangan para Hakim Pengadilan Agama telah dilakukan penyusunan Kompilasi Hukum Islam, suatu langkah lebih maju dari keadaan sebelumnya. ${ }^{38}$

Sebelum tersusunnya Kompilasi Hukum Islam tersebut, para Hakim Pengadilan Agama dalam mengambil keputusan-keputusannya berpedoman kepada kitab-kitab fiqih yang telah ditentukan yang memungkinkan munculnya kecenderungan menganut pendapat ulama meskipun dari mazhab yang sama, tetapi pendapatnya berbeda-beda. Sehingga tidak mustahil dalam kasus yang sama, dikeluarkan putusan yang berbeda. Kompilasi Hukum Islam dipilah menjadi tiga buah buku: (1) hukum perkawinan dan permasalahannya, (2) hukum kewarisan, wasiat dan hibah, (3) hukum wakaf dan pengelolaan harta wakaf. Meskipun belum sekuat Undang-Undang, namun jika Kompilasi Hukum Islam benar-benar hadir dan disahkan menjadi pedoman putusan-putusan Peradilan Agama, maka pelaksanaan hukum Islam akan semakin luas dan mantap dibanding dari keadaan sebelumnya. 
Pengembangan masuknya unsur-unsur hukum Islam dalam peraturan perundang-undangan lebih lanjut dalam rangka pembangunan Hukum Nasional selalu terbuka jalannya, sejalan dengan keharusan konstitusional yuridis sebagaimana disebutkan di atas. Persoalan sekarang adalah bagaimana caranya agar ketentuan hukum Islam itu dapat dipahami, disadari dan dirasakan sebagai alternatif yang mendatangkan rahmat bagi seluruh bangsa Indonesia yang notabene mayoritas menganut agama Islam yang oleh ajaran agamanya diwajibkan tunduk kepada hukum Islam.

Sebagaimana diketahui bahwa hukum Islam ada yang termaktub dalam nash Al-Qur'an dan Sunnah dan ada pula yang merupakan hasil ijtihad pada fuqaha'. Hukum-hukum nash dipertanyakan sejauh mana sifat mengikatnya, mutlak atau tidak mutlak, sejauh mana membedakan antara isi yang tersurat dalam permukaan dan jiwa yang terkandung di dalamnya, sejauh mana harus dipertahankan sebagaimana termaktub dalam nash dan kemungkinan diadakan variasi penerapannya bila berhadapan dengan kenyataan-kenyataan sosial yang dijumpai di suatu tempat pada masa tertentu. Mengenai hukum-hukum ijtihadiyah tidak menjadi masalah, sebab ijtihad tidak mempunyai kekuatan mengikat seperti hukum-huikum nash. Perubahan pada hukum-hukum ijtihad sangat dimungkinkan, sesuai tuntutan perubahan yang terjadi dalam kehidupan masyarakat.

Telah banyak dilotarkan pemikiran-pemikiran tentang hukum Islam oleh banyak kalangan. Yang sangat gencar adalah tendangan "bola salju pemikiran" dari Munawir Sjadzali dalam banyak kesempatan. Dan ternyata "bola salju" yang diistilahkan "reaktualisasi" itu mendapat banyak respon dari berbagai kalangan baik yang pro maupun yang kontra. ${ }^{39} \mathrm{Hal}$ ini dapat dimaklumi, karena yang menggelindingkan bola salju reaktualisasi itu adalah seorang Menteri Agama, ditambah cara melontarkannya dengan sangat menarik dan materi yang dilontarkannya pun sangat aktual. Kemudian masih ditambah lagi adanya kaitan dengan penerapan hukum Islam melalui lembaga Peradilan Agama, sehubungan dengan upaya melahirkan Kompilasi Hukum Islam sebagaimana telah disebutkan di atas.

Masalah-masalah yang digelindingkan di sekitar pemikiran-pemikiran hukum Islam itu meliputi masalah-masalah yang cukup mendasar, seperti ruh syari'ah, tujuan syari'ah, antara pemahaman tekstual dan kontekstual, penerapan asas mashlahah, kemungkinan memberlakukan nasakh, nilai permanen dan temporal, masalah qath'i dan zhanni, antara permukaan dan kedalaman, antara kulit dan inti, muncul pula istilah ijtihad ilahiyah dan sebagainya. Inti masalahnya adalah bagaimana caranya agar hukum Islam dapat disesuaikan dengan perkembangan sosio-kultural bangsa Indonesia yang berbeda dengan sosiokultural bangsa Arab di saat al-Qur’an diwahyukan dan Sunnah diucapkan.

Uraian berikut membicarakan hukum Islam yang termaktub dalam nash dan bagaimana kemungkinannya diterapkan dalam kehidupan masyarakat muslim khususnya di Indonesia, bagaimana kemungkinannya dapat terangkat dalam deretan pasal-pasal undang-undang positif serta muncul dalam yurisprudensi pengadilan. Di akhir pembahasan diberikan uraian singkat tentang hukum-hukum ijtihadiyah. 
Al-Qur’an merupakan pedoman umat sepanjang masa sampai hari kiamat kelak telah merangkum segenap aspek ajaran bagi kehidupan secara menyeluruh. Di antara ajaran-ajaran al-Qur'an ada yang sifatnya rinci (tafshili) dan global, berupa kaidah-kaidah umum. Untuk memperoleh penjelasan bagi ajaran-ajaran yang masih global diperlukan Sunnah Rasul. Terhadap al-Qur`an, Sunnah Rasul dapat berfungsi sebagai penguat (mu`akkid), penjelas (mubayyin) dan dapat pula menetapkan hal baru yang tidak disinggung dalam al-Qur'an, tetapi ketetapan itu juga tidak terlepas dari bimbingan wahyu. Al-Qur`an merupakan sumber pertama ajaran Islam dan Sunnah adalah sumber kedua. ${ }^{40}$

Menurut Azhar Basyir, aturan-aturan yang terdapat dalam al-Qur`an ada yang wajib diterima sebagaimana adanya dan ada pula yang dapat dipikirkan lebih lanjut realisasinya. Yang pertama biasanya disebut sebagai ghairu ma'qul al$m a^{\prime} n a$ atau ta'abbudi, sedangkan yang kedua sering disebut maq'ul al-ma'na atau ta'aqquli. Kategorisasi aturan-aturan al-Qur'an demikian itu memberikan arah bagian-bagian aturan mana yang memang tidak dapat ditawar-tawar (absolut) dan bagian mana yang mungkin diadakan modifikasi. Namun, sebagai pedoman dasar, al-Qur'an memerintahkan agar umat beriman taat kepada Allah, taat kepada Rasul dan ulul amri (QS. 4: 59).41

Hukum-hukum ibadah, meskipun ada beberapa yang mengundang perbedaan pendapat umumnya digolongkan ke dalam kelompok ghairu ma'qul al-ma'na yang tidak dapat ditawar, wajib dilaksanakan sebagaimana adanya. Berbeda dengan hukum-hukum muamalat, ada yang tergolong pada ghairu $m a^{\prime} q u l$ al-ma'na dan ada pula yang tergolong ma'qul al-ma'na. Ketentuan tentang masa 'iddah isteri yang ditinggalkan mati atau diceraikan suaminya masuk pada kategori ma'qul al-ma'na dan ini dapat menerima modifikasi. Angka-angka pecahan (persentase) dari bagian-bagian warisan bagi ahli waris dzawil furudh termasuk ghairu ma'qul al-ma'na, tidak menerima modifikasi. Jika kemudian hendak dikhususkan yang menyangkut bagian ahli waris lain. Masih dipertanyakan dapatkah suatu sistem dikeluarkan dari komponennya lalu dipikirkan tersendiri untuk kemudian diadakan modifikasi. Hal inilah yang mengundang banyak tanggapan, ketika Munawir Sjadzali melontarkan pemikiran hukum Islam yang diberi judul "Reaktualisasi Ajaran Islam," yang didalamnya mempertanyakan mengapa perolehan anak laki-laki dan anak perempuan dari harta warisan orang tuanya yang ditentukan berbanding 2:1 tidak dapat diadakan modifikasi?. Ta'lil al-ahkam ${ }^{42}$ ditawarkan latar belakang sosio-kultural ketika ketentuan tersebut disyari'atkan diimbau agar dapat menjadi pertimbangan.

Menurut Azhar Basyir, nilai keadilan dalam ketentuan berbanding 2: 1 tercermin dalam ketentuan hukum yang mewajibkan kaum laki-laki memikul nafkah keluarga, sesuai fitrahnya. Ketentuan tersebut dianut juga oleh UU. No. 1 Tahun 1974 Pasal 34 Ayat (1). Ketentuan tersebut juga konsisten dalam pembagian warisan yang diperuntukkan bagi suami dan istri $(1 / 2$ bagi suami dan $1 / 4$ bagi isteri jika tidak ada anak atau cucu, $1 / 4$ bagi suami dan $1 / 8$ bagi 
isteri jika ada anak atau cucu). Demikian juga antara ayah dan ibu dalam hal tidak ada anak dan cucu (ibu mendapat bagian 1/3 dan ayah mendapat sisanya). Karena ketentuan itu sesuai dengan fitrah, ketentuan tersebut merupakan ketentuan hukum asal yang wajib ditaati. 43

Ketentuan hukum al-Qur'an berkenaan dengan persaksian perjanjian utang-piutang dengan perbandingan 2:1 bagi saksi perempuan dan saksi lakilaki, dapat dikelompokkan ke dalam hukum yang ma'qul al-ma'na, bukan bilangan saksi menjadi tekanan, tetapi tercapainya kebenaran di dalam persaksian yang menjadi tujuan. Di sini ta'lil al-ahkam dapat menjadi pertimbangan kemungkinan adanya modifikasi. Sejenis dengan hukum persaksian wanita itu, adalah masalah menyangkut hakim wanita di Pengadilan Agama, baik sebagai hakim anggota maupun sebagai hakim ketua, atas dasar ketentuan ajaran Sunnah Rasul yang menyatakan bahwa suatu kaum tidak akan berjaya jika menyerahkan urusan-urusan kepada wanita. Ini juga termasuk kelompok ma'qul al-ma'na, di mana ta'lil al-ahkam dapat menjadi pertimbangan interpretasi.

Interpretasi hukum-hukum nash banyak dilakukan oleh Khalifah 'Umar bin Khaththab terhadap hukum-hukum yang $m a^{\prime} q u l$ al-ma'na. Ada yang bertumpu pada ta'lil al-ahkam, seperti dalam masalah pemberian zakat kepada mu allaf qulubuhum, ${ }^{44}$ dan ada yang berupa tidak menerapkan hukum nash karena tidak memenuhi syarat-syarat penerapannya, seperti dalam kasus pencurian yang dilakukan pada musim paceklik. Juga ada yang bersifat membendung terjadinya permainan terhadap ketentuan hukum syara', seperti dalam masalah talak tiga yang dijatuhkan sekaligus. Kemudian ada yang sifatnya mengutamakan tercapainya ketentuan hukum yang lebih umum, meskipun harus meninggalkan ketentuan hukum khusus yang dalam istilah fuqaha Hanafiah disebut istihsan, seperti dalam masalah pemberian hak atas empat perlima rampasan perang kepada para prajurit yang ikut berperang yang kemudian tidak dilaksanakan oleh Khalifah 'Umar karena negara sangat memerlukan tambahan pendapatan yang diperlukan untuk pertahanan negara. Hudzaifah ibn al-Yaman dilarang menikah dengan perempuan ahli kitab di Madain, karena kedudukannya sebagai wali negeri (gubernur) jika jejaknya diikuti kaum laki-laki muslim akan menimbulkan fitnah terhadap wanita-wanita muslimah. Al-Qur`an surat alMa idah ayat 5 yang mengizinkan laki-laki muslim mengawini wanita ahli kitab tidak diberlakukan oleh Khalifah 'Umar terhadap Gubernur Hudzaifah ibn alYaman guna menjaga terjadinya fitnah terhadap wanita-wanita muslimah. ${ }^{45}$ Penafsiran hukum demikian disebut sadd al-dzara'i. Istihsan dan sadd al-dzara'i merupakan dua macam jalan terobosan untuk meninggalkan ketentuan hukum nash sebagai kekecualian. Beda antara istihsan dan sadd al-dzara'i adalah yang pertama biasanya merupakan terobosan kekecualiaan untuk memperoleh pembenaran dalam melanggar larangan, sedangkan yang kedua adalah terobosan kekecualian untuk melarang sesuatu yang dibolehkan syara'.

Peluang pikiran terhadap hukum-hukum ijtihadiyah sangat luas. Hasil ijtihad tidak memiliki daya mengikat seperti hukum-hukum nash. Ijtihad adalah pemikiran mendalam dengan menggunakan metode secara jelas di dalam nash al-Qur`an atau Sunnah, tetapi tetap berpedoman kepada jiwa hukum nash, tujuan hukum nash, atau illat hukum nash. Penemuan hukum dengan jalan ijtihad 
memungkinkan terjadinya perbedaan pendapat di kalangan mujtahidin terhadap suatu ketentuan hukum. Perubahan-perubahan hukum-hukum ijtihadiyah sangat mungkin terjadi; tidak selalu perubahan terjadi karena ijtihad orang lain; tetapi dapat juga terjadi pada diri seorang mujtahid yang mengubah pendapatnya yang lama dengan pendapatnya yang baru. Dengan kata lain, seorang mujtahid dapat membatalkan hasil ijtihad yang lama dengan ijtihadnya yang baru. Imam Syafi'i misalnya, ada qaul qadim dan qaul jadid-nya.

Memperhatikan bahwa masalah kehidupan bermasyarakat dewasa ini makin kompleks, maka pemecahannya pun memerlukan partisipasi dari banyak tenaga ahli, sehingga amat sukar seorang tenaga ahli dapat menemukan pemecahan atas persoalan-persoalan masyarakat tanpa bersama-sama dengan tenaga ahli lainnya. Karena itu, menurut Azhar Basyir, ijtihad dalam hukum Islam harus dilakukan secara jama'iy (bersama-sama), tidak secara fardi (perseorangan). Ijtihad jama'iy bila didukung dengan fasilitas-fasilitas kenegaraan, tanpa mengurangi kebebasan para mujtahid akan lebih berhasil. Lembaga-lembaga ijtihad berwawasan internasional sangat diperlukan guna memecahkan masalah-masalah bersama tanpa mengurangi kemungkinankemungkinan bervariasinya pelaksanaan hasil ijtihad bersama sesuai dengan tuntutan ruang dan waktu sepanjang masih dalam kerangka ruh syari'at Islam. ${ }^{46}$

Berkenaan dengan masalah-masalah yang menjadi kepentingan masyarakat luas tegas Azhar Basyir ijtihad fardi sebaiknya dihentikan untuk menghindari kebingungan masyarakat terhadap ijtihad fardi yang sangat mungkin saling berbeda. Persiapan tenaga-tenaga mujtahid hendaknya dilakukan dengan sungguh-sungguh baik melalui pendidikan formal maupun informal. Spesialisasi bidang-bidang ijtihad kiranya telah tiba saatnya untuk dipikirkan mengingat makin kompleksnya masalah-masalah kehidupan dewasa ini. kodifikasi atau sekurang-kurangnya kompilasi hukum Islam sangat membantu pemasyarakatan hukum Islam bahkan sangat besar artinya bagi pembangunan hukum nasional mengingat bahwa bagian terbesar warga negara Indonesia adalah umat Islam yang atas dasar yuridis konstitusional, yaitu sila Ketuhanan Yang Maha Esa secara kenegaraan wajib mengamalkan ajaran-ajaran agama yang diyakininya. ${ }^{47}$

Dalam sebagian literatur hukum yang membahas tentang ijtihad, sering ditemukan adanya suatu bahasan tentang tertutupnya pintu ijtihad. Istilah ini semakin jarang ditemukan dalam literatur hukum Islam karya ulama mut akhkhirin.

Dibahas tidaknya tentang tertutupnya pintu ijtihad ditentukan oleh corak pandang ulama yang memaparkan pembahasan tentang ijtihad itu. Ulama yang melihat ijtihad sebagai sesuatu yang sulit dan berat, beranggapan bahwa ijtihad itu hanya dapat dilakukan ulama-ulama besar pembangun mazhab, seperti Imam Abu Hanifah, Imam Malik, Imam Syafi'i dan Imam Ahmad ibn Hanbal. Ulama sekarang menurut mereka tidak dapat melakukan ijtihad itu.

Ulama yang lain melihat bahwa ijtihad memang bukan suatu pekerjaan yang ringan, namun demikian tetap diperlukan. Karena persoalan-persoalan hukum senantiasa muncul sesuai dengan kebutuhan, tuntutan tempat dan waktu. Ketiadaan ijtihad dapat melahirkan kevakuman hukum. Persoalan- 
persoalan hukum muncul tanpa batas tempat dan waktu, sedangkan nash-nash sangat terbatas, oleh karena itu ijtihad harus dilakukan. ${ }^{48}$

Upaya ijtihad dewasa ini berbeda dengan upaya ijtihad pada masa yang lalu. Hal ini disebabkan persoalan-persoalan yang muncul lebih kompleks. Pemecahannya memerlukan pendekatan yang tidak hanya dari aspek hukum semata akan tetapi memerlukan pengkajian dari berbagai disiplin seperti ilmu kesehatan, psikologi, ekonomi dan politik. ${ }^{49}$ Disiplin-disiplin ilmu ini secara keseluruhan tidak dapat dikuasai oleh satu orang saja. Di samping itu disiplin ilmu-ilmu keislaman itu sendiri tidak dapat dikuasai oleh satu orang. Pendalaman dan spesialisasi dilakukan oleh masing-masing orang.

Melihat kenyataan ini, memang bentuk ijtihad yang baik dilakukan adalah ijtihad jama'i (ijtihad kolektif) bukan ijtihad fardi (ijtihad perorangan). Pemikiran yang merupakan produk kerja sama dari berbagai sudut pandangan keilmuan lebih dapat mendekati kebenaran dan lebih kuat dari hasil pemikiran secara tersendiri dengan hanya satu sudut pandang.

Menurut Harun Nasution, yang diperlukan memang ijtihad kolektif tetapi yang lebih dibutuhkan ijtihad kolektif berskala nasional, bukan internasional. Sebab masalah keagamaan yang muncul di zaman kemajuan ilmu pengetahuan dan teknologi ini tidak sama, di samping beragamnya penafsiran dan pengamalan agama di negara-negara Islam. ${ }^{50}$

Penerapan bentuk ijtihad kolektif dapat memungkinkan pemenuhan persyaratan-persyaratan ijtihad sebagaimana dikehendaki dalam Islam. Hanya cara pemenuhan persyaratan itulah yang berbeda.

\section{Penutup}

Hukum Islam dalam kehidupan masyarakat hendaknya dilakukan kajian dan ijtihad jama'i (ijtihad kolektif). Masalah-masaalah yang menyangkut kepentingan masyarakat tidak bisa diselesaikan dengan ijtihad fardi (ijtihad perorangan), agar hasilnya lebih mantap. Ijtihad perorangan yang mungkin berakibat membingungkan umat, seyogyanya dihindari dan dihentikan.

Pemikiran Azhar Basyir dan kaitannya dengan pembangunan hukum nasional adalah terbukanya peluang bagi umat Islam untuk mengajukan konsepkonsep syari'at Islam agar peraturan perundang-undangan yang berlaku tidak menyimpang dari ketentuan syari'at Islam. Upaya ke arah itu selalu terbuka dan sejalan dengan keharusan konstitusional yuridis yang tidak bertentangan dengan Pancasila dan UUD 1945.

Berkaitan dengan dinamika hukum Islam di Indonesia, pemikiran Ahmad Azhar Basyir mempunyai peranan yang signifikan terhadap lahirnya UU No. 7/1989 (tentang Peradilan Agama) dan Kompilasi Hukum Islam Indonesia.

\section{Catatan akhir:}

1 Abdul Azis Dahlan, et.al. (Ed.), Ensiklopedi Hukum Islam, Jilid I, (Jakarta : P.T. Ichtiar Baru van Hoeve, 1999), hlm. 156

${ }^{2}$ Muhammad Abu Zahrah, Ushul Figh, (Cairo : Dar al-Fikr al-'Arabi, 1958), hlm. 21 
3 Mushthafa Ahmad al-Zarqa', Al-Figh al-Islami fi Tsaubihi al-Jadid, (Damaskus : Mathba'ah Jami'ah, 1959), hlm. 29

${ }^{4}$ Dalam bentuk konsep lain, ajaran Islam dapat dibedakan menjadi dua kelompok ajaran. Pertama, ajaran Islam yang bersifat absolut, universal, dan permanen, tidak berubah dan tidak dapat diubah. Termasuk kelompok ini adalah ajaran Islam yang tercantum dalam al-Qur`an dan Hadis mutawatir yang penunjukkannya telah jelas (qath'i al-dalalah). Kedua, ajaran Islam yang bersifat relatif, tidak universal dan tidak permanen. Dapat berubah dan diubah. Termasuk kelompok kedua ini adalah ajaran Islam yang dihasilkan melalui proses ijtihad. Lihat: Yusuf al-Qardhawi, Al-Ijtihad fi al-Syari'ah alIslamiyah ma'a Nazhariyah fi al-Ijtihad al-Mu'ashir, (Kuwait : Dar al-Qalam, 1985), hlm. 205

5 Ahmad Azhar Basyir, Refleksi atas Persoalan Keislaman : Seputar Filsafat, Hukum, Politik, dan Ekonomi, (Bandung : Mizan, 1993), hlm. 129

6 Maqashid merupakan bentuk jama' dari kata maqshid yang berarti tuntutan, kesengajaan atau tujuan. Lihat: Hans Wehr, A Dictinory of Modern Written Arabic, J. Milton Cowan (ed.), (London : MacDonald \& Evans LTD., 1980), hlm. 767. Menurut istilah, maqashid aal-syari'ah adalah kandungan nilai yang menjadi tujuan persyaratan hukum. Lihat : Ahmad al-Hajj al-Kurdi, Al-Madkhal al-Fiqhi : al-Qawa'id al-Kulliyah, (Damaskus : Dar al-Ma'arif, 1980), hlm. 186

${ }^{7}$ Ahmad Azhar Basyir, Refleksi..., loc.cit.

8 Ibid., hlm. 130

9 Lihat : Assaf A.A. Fyzee, Outlines of Muhammadan Law, (London : Oxford University Press, 1955), hlm. 137-138

10 Ibid.

11 Ibid., hlm. 131

12 Ibid.

${ }^{13}$ Ahmad Azhar Basyir, "Pokok-pokok Ijtihad dalam Hukum Islam," dalam Haidar Baqir, Ijtihad dalam Sorotan, (Bandung : Penerbit Mizan, 1998), hlm. 47

14 Ahmad Azhar Basyir, Refleksi..., op.cit., hlm. 132

15 Ibid.

${ }^{16}$ Ahmad Azhar Basyir, "Pokok-pokok..., op.cit., hlm. 49

17 Ahmad Azhar Basyir, Refleksi..., loc.cit.

18 Ibid.

${ }^{19}$ Ahmad Azhar Basyir, “Pokok-pokok..., op.cit., hlm. 52

${ }^{20}$ Ahmad Azhar Basyir, Refleksi..., op.cit. hlm. 133

21 Ibid.

22 Ahmad Azhar Basyir, Ikhtisar Fikih Jinayat (Hukum Pidana Islam), (Yogyakarta : UII Press, 2001), hlm. 38

${ }^{23}$ Ahmad Azhar Basyir, Refleksi..., op.cit., hlm. 134

24 Ibid.

25 Al-Ghazali, Ihya' 'Ulum al-Din, Jilid III, (Indonesia : Dar Ihya' al-Kutub al'Arabiyah, t.th.), hlm. 52

${ }^{26}$ Di samping itu, ada yang membagi kepada tauhid rububiyah, tauhid uluhiyah, dan tauhid hakimiyah. Lihat: Daud Rasyid, Islam dalam Berbagai Dimensi, (Jakarta : Gema Insani Press, 1998), hlm. 18-21

27 Muhaimin dan Abd. Mujib, Pemikiran Islam : Kajian Filosofis dan Kerangka Dasar Operasionalnya, (Bandung : Trigenda Karya, 1993), hlm. 47-51

28 Lihat : Peunoh Daly, "Taklif dan Mukallaf" dalam Ismail Muhammad Syah, et.al., Filsafat Hukum Islam, (Jakarta : Bumi Aksara, 1992), hlm. 163. Lihat pula Muhammad Muslehuddin, Philosophy of Islamic Law and Orientalits, (Lahore : Islamic Publication Ltd., 1980), hlm. 228-238 
${ }^{29}$ Ahmad Azhar Basyir, Refleksi..., op.cit., hlm. 138

${ }^{30}$ Muhammad Muslehuddin, op.cit., hlm. 52

${ }^{31}$ Dalam kesusilaan umum, adat berpakaian senantiasa berubah, dahulu memakai emban dengan memperlihatkan sebagian dadanya merupakan perbuatan yang terhormat, namun kemudian perbuatan tersebut dianggap sebagai perbuatan yang melanggar ketentuan moral yang terpuji. Untuk mengantisipasi semua perbuatan ini Islam mempunyai suatu pijakan yang tetap bahwa perempuan harus menutupi perhiasan dirinya. Lihat : Ibid., hlm. 113-114

32 Dalam al-Qur'an tidak ada perbedaan yang jelas antara moral dan peraturan hukum. Al-Qur'an membicarakan hal-hal fundamental untuk membedakan yang hak dan yang batil, baik dan buruk, yang pantas dan yang tidak pantas. Ajaran al-Qur'an semata-mata menunjukkan standar tingkah laku yang dapat diterima dan tidak dapat diterima oleh Allah. Lihat : N.J. Coulson, Conflict and Tensions in Islamic Jurisprudence, (Chicago : t.p., 1969), hlm. 12

${ }^{33}$ Hazirin, Tujuh Serangkai Tentang Hukum, (Jakarta : Tintamas, 1974), hlm. 87

${ }^{34}$ Muhammad Muslehuddin, op.cit., hlm. 179-180

${ }^{35}$ H.A.R. Gibb, Modern Trends in Islam, (Chicago : t.p., 1947), hlm. 35

${ }^{36}$ Abdul Azis Dahlan, et.al. (Ed.), Ensiklopedi Hukum Islam, Jilid I, (Jakarta: P.T. Ichtiar Baru van Hoeve, 1999), hlm. 156

${ }^{37}$ Ahmad Azhar Basyir, Refleksi..., op.cit., hlm. 141

38 Ibid., hlm. 141-142

${ }^{39}$ Lontaran pemikiran Munawir Sjazdali tentang reaktualisasi akhirnya menjadi polemik panjang di Majalah Panji Masyarakat, dan bahkan polemik tersebut telah dibukukan oleh Penerbit Panjimas

40 'Ali Hasaballah, Ushul al-Tasyri' al-Islami, (Mesir : Dar al-Ma'arif, 1976), hlm. 16

${ }^{41}$ Ahmad Azhar Basyir, Refleksi..., op.cit., hlm. 143

${ }^{42}$ Melakukan ijtihad terhadap hukum nash dapat ditempuh dengan cara meneliti sebab ('illat) hukum yang melatarbelakangi ketentuan hukum. 'Illat hukum inilah yang merupakan salah satu sendi qiyas, sebagaimana telah disebutkan di muka. Selain dipergunakan untuk melakukan qiyas, 'illat hukum dapat juga dipergunakan untuk menetapkan, apakah sesuatu ketentuan hukum nash tetap berlaku atau tidak, jika ternyata 'illat hukumnya tidak terdapat pada suatu ketika. Atau, dengan rumusan yang lebih ringan, mengaitkan berlakunya hukum dengan 'illatnya memungkinkan tidak dilaksanakannya ketentuan hukum jika 'illatnya tidak terlihat pada suatu ketika. Lihat: Ahmad Azhar Basyir, "Pokok-pokok..., op.cit., hlm. 56

${ }^{43}$ Ahmad Azhar Basyir, Hukum Waris Islam, (Yogyakarta : UII Press, 2001), hlm. 187-188

${ }^{44}$ Pada masa khalifah Umar ibn Khattab kelompok mu `allafah qulubuhum (orangorang yang sedang dibujuk hatinya untuk memeluk Islam) tidak diberikan zakat. Kelompok ini pada masa Nabi mendapat bagian zakat sesuai ddengan penegasan nash yang bertujuan mengajak manusia memeluk Islam, di mana Islam dalam posisi masih lemah. Ketika Islam dalam posisi yang kuat, maka pelaksanaan zakat dengan tujuan untuk sementara itu, tidak dilaksanakan. Lihat :'Ali Hasaballah, op.cit., hlm. 93-94

${ }^{45}$ Ahmad Azhar Basyir, "Pokok-pokok..., op.cit., hlm. 60-61

${ }^{46}$ Ibid., hlm. 62

${ }^{47}$ Ibid.

${ }^{48}$ Nadiyah Syarif al-`Umri, Al-Ijtihad fi al-Islam : Ushuluhu, Ahkamuhu, Afaquhu, (t.t. : Mu`assasah al-Risalah, 1981), hlm. 259 
Al-Fikra: Jurnal Ilmiah Keislaman, Vol. 4, No. 1, Januari-Juni 2005

${ }^{49}$ Lihat : Satria Effendi, "Fiqh Muamalat : Suatu Upaya Rekayasa Sosial Umat Islam di Indonesia," dalam Makalah Seminar Aktualisasi Muamalat dalam Kehidupan Dewasa Ini, (Medan : IAIN Sumatera Utara, 1989), hlm. 17

${ }^{50}$ Harun Nasution, "Ijtihad Sumber Ketiga Ajaran Islam," dalam Haidar Baqir (ed.), Ijtihad dalam Sorotan, (Bandung : Penerbit Mizan, 1988), hlm. 115 